TEME, г. XLI, бр. 1, јануар-март 2017, стр. 23-38

Прегледни рад

DOI: $10.22190 /$ TEME1701023M

Примљено: 20. 10. 2015.

UDK 159.922 .2

Ревидирана верзија: 11. 08. 2016.

Одобрено за штампу: 17. 01. 2017.

\title{
ОД ЕКОЛОШКЕ КА БИОЕКОЛОШКОЈ ТЕОРИЈИ ЉУДСКОГ РАЗВОЈА - ЧОВЕК И ОКРУЖЕНЕ У ДИЈАЛОГУ
}

\author{
Јована Маројевић \\ Универзитет Црне Горе, Филозофски факултет, Подгорица, Црна Гора \\ jovanar@ac.me
}

\begin{abstract}
Апстракт
Рад представља преглед развојног пута биоеколошке теорије Ј. Бронфенбренера и њених кључних одлика у свим фазама стварања. Од првог интегралног излагања ове теорије до њене зреле форме протећи ће скоро три деценије. Тај пут означен је суштинским прелазом од еколошке ка биоеколошкој концепцији развоја. Будући да се ова развојна теорија често концептуализује као само еколошка, те да се, нарочито у истраживачком домену, пренебрегава њена ревидирана и целовита верзија, важно је упознати се са њеним развојним путем, посебно ако се претендује на биоеколошки валидно утемељено истраживање. Аналитичари Бронфенбренерове теорије препознали су веома мали број истраживања, међу свим декларативно позиционираним на биоеколошкој теорији, који заправо примењују биоеколошки „РРСТ” (енгл.) модел као истраживачки дизајн. Потреба за оваквим прегледом ове „теорије у развоју” посебно је потцртана чињеницом да је на нашим просторима у преводу доступна управо прва, еколошка верзија Бронфенбренерове теорије (1997, Екологија људског развоја).
\end{abstract}

Кључне речи: биоеколошка развојна теорија, еколошке средине, проксимални процеси, „РРСТ” (енгл.) модел, J. Bronfenbrener.

\section{FROM ECOLOGICAL TO BIOECOLOGICAL THEORY OF HUMAN DEVELOPMENT - MAN AND ENVIRONMENT IN DIALOG}

\begin{abstract}
The paper represents an overview of the developmental line of J. Bronfenbrenner's bioecological theory and its key characteristics in each developmental phase. It took three decades from the first integral representation of this theory to its mature form. That line is marked by an essential shift from the ecological to bioecological concept of human development. If we pretend to conduct a biecological valid research, it is very important to learn about teh development of this theory, even more since it is very often conceptualized as only ecological, without using its revised and complete version in
\end{abstract}


research. The analysts of the Bronfenbrenner theory recognized only a few researche, among all that are declarative based on bioecological theory, that really uses bioecological "PPCT" model as the research design. The need for this kind of overview of this "theory in development" is highlighted more by the fact that in our region is available the very first, ecological version of the Bronfenbrenner's theory (1997, Екологија људског развоја).

Key words: bioecological theory of development, ecological system, proximal processes, „PPCT“ model, J. Bronfenbrenner.

\section{УВОД}

Бронфенбренерова ${ }^{1}$ теорија људског развоја је, од зачетка (шездесетих година прошлог века), па до ауторове смрти (2005), била у непрестаном процесу мењања и развоја. И сам аутор разликује два периода у развоју теорије - почетне идеје о људском развоју изнесене у Екологији људског развоја (1979) и каснија ревидирања теорије у неколико кључних радова током осамдесетих и деведесетих година 20. века (Bronfenbrenner, Evans, 2000: 116). Неки аналитичари говоре о три кључне фазе у развоју биоеколошке теорије људског развоја (Rosa, Tudge, 2013: 243).

Прво свеобухватно експлицирање теорије о екологији људског развоја аутор је начинио 1970. и 1979. године у делу „Екологија људског развоја: природни и дизајнирани експерименти”. Теоријска парадигма коју Бронфенбренер износи била је, између осталог, нека врста реакције на дотадашњу развојну психологију за коју и сам аутор у свом чланку из 1977. године каже да је „наука о чудном понашању деце у чудним ситуацијама са чудним одраслима у најкраћим могућим временски периодима" (Bronfenbrenner, 1977: 513). Основни мотиви који су покренули Бронфенбренерово настојање да уобличи тада еколошку теорију људског развоја били су пре свега у увиђању ограничења дотадашњих истраживања људског развоја подузиманих искључиво у лабораторијским условима, али и у захтевима социјалне политике релевантне за децу, омладину или породице (Rosi, Tudge, 2013: 245). Теорија је постављена од стране Бронфенбренера као покушај да се објасни како се одвија људски развој, са значајном пажњом посвећеном улози контекста у том процесу. Он је сматрао да развој израста из интеракције особе и окружења. У овом капиталном делу Бронфенбренер се не усредсређује на неки специфични домен развоја (социјални, когнитивни и слично), већ

\footnotetext{
${ }^{1}$ Јури Бронфенбренер (1917-2005), развојни психолог, творац (био)еколошке теорије људског развоја; најзначајнија дела: Two Worlds of Childhood: U.S. and U.S.S.R. (1970), The Ecology of Human Development (1979), Making Human Beings Human (2005). Осим тога, објавио је на десетине истраживачких радова, критика и есеја о људском развоју.
} 
приказује линију развоја појединца током целог његовог живота, фокусирајући се на указивање везе између различитих развојних процеса и контекстуалних варијабли, и то на начин постављања десетина проверљивих хипотеза. Неки критичари сматрају како се често пренебрегава управо ова вредност поменуте књиге - грађа која је у њој понуђена а која се може, и треба, тестирати - те да је заправо мали број истраживања која су била усредсређена на проверавање изнесених претпоставки (Darling, 2007: 203). Насупрот томе, Бронфенбренеру се углавном одаје почаст што је указао на важност утицаја контекстуалних варијација на људски развој и што је развојну психологију у том смислу учинио више „еколошки валидном” инсистирајући на истраживањима особе у развоју у њеном природном окружењу. Исто тако, његов рад се често концептуализује у виду дијаграма „еколошке теорије”, као систем концентричних кругова, у чијем центру је дете. Ипак, неки аутори у овоме не виде суштину и највећи значај Бронфенбренерове научне заоставштине (Darling, 2007: 204).

Ова концептуализација теорије из 1979. године касније је пропраћена интегративним реформулацијама из 1983. и 1998. године, кроз извесну критику модела изнесеног у Екологији људског развоја (Bronfenbrenner, Evans 2000: 116). У току осамдесетих већ се конституише концепт „процес-особа-контекст”, но, како сам аутор тврди, није дефинисано шта се заправо мисли под процесом (Bronfenbrenner, Morris, 2006: 799), а што је још важније, изостаје компонента „време” као једна од дефинишућих у коначном теоријском биоеколошком моделу (Bronfenbrenner, 1995: 622, Bronfenbrenner, Morris, 2006: 799). Ипак, осетно је померање тежишта теорије са контекста на особу, односно проксималне процесе као кључне чиниоце развоја. Каснијим реформулацијама првобитних идеја, пажња је пре свега усмерена на улогу коју појединац игра у сопственом развоjy; на утицај времена на развојни процес и, више од свега, на носећи термин развијене, потпуне биоеколошке теорије људског развоја проксимални процес (Rosa, Tudge, 2013: 244). Прелаз са еколошке на биоеколошку теорију управо је показатељ значајног померања тежишта на улогу појединца у сопственом развоју. Неки елементи присутни у првобитној теорији безмало ишчезавају из каснијих верзија, као што су концепти моларних активности, еколошке валидности и еколошких прелаза и слично (Tudge et al., 2009: 199). Особа, а не сами контекст и окружење јесу у центру Бронфенбренеровог разматрања у другој фази развоја теорије, сматрају неки аналитичари екологије људског развоја (Darling, 2007: 207; Tudge et al., 2009: 199; Rosa, Tudge, 2013: 252). И сам аутор је истицао тај прелаз са фокуса теорије на окружење, ка центрирању исте на процесима (проксимални процеси), који све до средине осамдесетих пак није добио своју званичну, писану форму (Bronfenbrenner, Morris, 2006: 794). Од средине деведесетих, у низу радова биоеколошка теорија добија своју „зре- 
лу” форму, са фокусом на проксималне процесе у центру „процесособа-контекст-време" модела (Tudge, et al., 2009: 198). Проксимални процеси одређују се као кључни покретачи развоја (Bronfenbrenner, Ceci, 1994; Bronfenbrenner, Morris, 2006). Неколико тема пак остаје актуелно у свим фазама његовог рада: важност друштвеног и историјског контекста, активност појединца и наглашавање немогућности разумевања развоја индивидуе у изолацији и независно од контекста у коме се развија (Darling, 2007: 204, 205).

\section{ОД , ЕКОЛОШКЕ” КА „БИОЕКОЛОШКОЈ” ТЕОРИЈИ}

Како је већ речено, Бронфенбренерова развојна теорија наглашено је динамичног типа и од зачетка идеје, па до коначне, зреле форме теорије - претрпела је значајне промене. Послужићемо се ауторовим препознавањем „фаза” у развоју биоеколошке теорије (Bronfenbrenner, Evans, 2000: 116, Bronfenbrenner, Morris, 2006: 794) и представићемо кључне појмове у свакој од њих, јасно оцртавајући сва ревидирања, новине или концепцијске промене које су начињене на њеном развојном путу.

\section{Екологија људског развоја}

Своје прво обухватно представљање еколошке развојне теорије Бронфенбренер је изложио у Екологији људског развоја 1979. године. Аутор своју развојну концепцију одређује као теоријску перспективу о људском развоју, која се креће у простору од особе у развоју и окружења, односно у простору њихове интеракције. Бронфенбренер дефинише развој као „процес путем кога особа у развоју усваја ширу, диференциранију и валиднију представу еколошке средине и постаје мотивисана и способна да се укључи у активности које откривају одлике средине, одржавају или реструктуришу ту средину на нивоима сличне или веће сложености облика и садржаја" (Bronfrenbrenner, 1997: 38), односно као „трајно мењање начина на који особа опажа своју средину и односи се према њој”, истичући при томе „неортодоксан концепт средине”, која подразумева еколошко окружење у виду скупа угнеждених структура (Bronfrenbrener, 1997: 13). Појединац се у овој теорији перципира као растући, променљиви, динамички ентитет; интеракција између особе и средине је двосмерна, односно, карактерише је реципроцитет. У том смислу, у предговору Екологији људског развоја, Мајкл Кол истиче како је Бронфренбренеров одговор на питање како да разумемо оно што чинимо сажет у синтагми „све зависи”, што значи да „објашњења... могу да се нађу у интеракцији између одлика људи и њихове средине, прошле и садашње”, те да је „интеракција главни ефекат” (Bronfrebrener, 1997: 4). 
Еколошка средина се не своди на једно, непосредно окружење, већ подразумева узајамне везе између окружења - она је, наиме, тополошки схваћена као угнеждени поредак концентричних структура (Bronfrebrener, 1997: 32, 33). У самом центру је непосредно окружење у коме је особа која се развија и оно представља микросистем. Појединачна окружења међу собом стварају интеракцију која такође утиче на појединца и одређује његов развој, и то ,једнако као што га одређују и збивања у оквиру појединог окружења", сматра аутор (Bronfrebrener, 1997: 13). Трећи ниво еколошког окружења подразумева утицај на развој појединца свих оних окружења у којима дете само и не учествује, а ипак значајно обликују дететов развој (аутор у том домену посебно апострофира услове запослења родитеља као фактор развоја детета из „трећег круга”). Напослетку се јавља и четврти круг утицаја, који подразумева деловање макро(суп)културе на развој појединца.

Еколошка средина, према Бронфренбренеру, превазилази непосредну ситуацију која индиректно утиче на особу која се развија, а једнака се пажња придаје везама између других особа која су у њеном окружењу. У самом центру те концентричне структуре је микросистем који подразумева образац ,активности, улога и интерперсоналних односа доживљених од стране особе у развоју у датом окружењу са одређеним физичким и материјалним карактеристикама” (Bronfrenbrener, 1997: 33). Окружење се дефинише као „место са одређеним физичким карактеристикама у коме појединац ступа у одређене активности узимајући одређене улоге (на пример, кћерка, родитељ, наставник, запослени итд.) у одређеном временском периоду" (Bronfrenbrener, 1997: 514). Кључни елементи окружења, па и микросистема су, дакле, активности, улоге и међуљудски односи у које појединац ступа. Сами по себи, поменути елементи микросистема не значе много за поимање развоја појединца - оно што је у истраживању развоја значајано јесте спознати како се поменути елементи доживљавају од стране особе у развоју. Ова феноменолошка перспектива остаје да важи и на другим нивоима еколошке структуpe, па тако аутор мезосистем дефинише као „однос између два или више окружења у којима особа која се развија активно учествује", односно, то је заправо систем микросистема (Bronfrebrener, 1997: 36). Кад је реч о развоју деце (пошто се еколошка развојна теорија односи на развој у било којој доби индивидуе), типични примери чланица мезосистема су средине породице и школе. Егзосистем подразумева ,једно или више окружења која не укључују особу у развоју као активног учесника, али у којима долази до збивања која утичу на, или на која утиче, оно што се дешава у окружењу у коме се налази особа у развоју" (Bronfrenbrener, 1997: 36). Напослетку, макросистемом „означавамо доследност, у облицима и садржајима система нижег реда (микро-, мезо-, егзо-), која постоји или би могла 
да постоји, на нивоу супкултуре или културе као целине, заједно са било којим системом веровања или идеологијом који леже у основи овакве доследности" (Bronfrenbrener, 1997: 36).

Кретање кроз еколошке средине, који је уједно и производ и покретач развојног процеса, означава се као еколошки прелаз и настаје кад се „положај особе у еколошкој средини мења као резултат промене улога, окружења или и једног и другог" (Bronfrenbrener, 1997: 37). Еколошки прелази су прави примери узајамне акомодације између организма и његове средине, те стога покретачи развоја. Њихов развојни значај лежи управо у промени улоге као скупа очекиваних понашања повезаних са одређеним положајем у систему, друштву. Активности у којима учествују други са дететом или се одвијају у његовом присуству представљају она срединска збивања која „најнепосредније и најмоћније утичу на развој особе” (Bronfrenbrener, 1997: 16). Као последица нових улога, активности и односа, дешавају се промене унутар саме особе; тако је сваки прелаз (еколошки) уједно и исход развојног процеса, али и стимулус за даљи paзвој (McMillan, 1990: 38). Прелази, као такви, с обзиром на то да по себи садрже стање „пре” и „после” могу послужити као савршена поља за истраживање, и то као својеврсни „експерименти природе” (Бронфенбренер одбија да их назове квазиекспериментима), у којима нема вештачког стварања експерименталних и контролних услова (McMillan, 1990: 38).

Функционисање поменуте структуре концентрично угнеждених еколошких средина окарактерисано је низом одлика и процеса, концепата којима се у каснијем развоју теорије Бронфенбренер није враћао и подробније их елаборирао (Bronfrenbrener, 1997)².

\section{Биоеколошка теорија људског развоја}

Како је већ наглашено, Бронфенбренерова еколошка теорија у потпуности је динамичког карактера, и као таква доживела је низ преображаја од почетне концептуализације крајем седамдесетих година прошлог века. Две кључне промене су унесене у првобитну верзију теорије деведесетих година: пре свега, догодио се прелаз од еколошке ка биоеколошкој теорији, наглашавајући тако значај учешћа појединца у сопственом развоју, и понуђен је сада потпуни методолошки модел за подузимање биоеколошких истраживања „Процес-Особа-Контекст-Вријеме” (Rosi, Tudge, 2013: 251). На овом месту представићемо зрелу и потпуну верзију еколошког модела, најобухватније исказану у Handbook of Child Psychology: Theoretical Models of Human Development (Lerner, M. R. (ed.), 2006).

\footnotetext{
${ }^{2}$ Моларне активности, дијаде, развојне дијаде, $\mathrm{H}+2$ системи, улоге.
} 
Бронфенбренер свој биоеколошки модел развоја смешта у контекст науке о развоју, коју дефинише као систематску науку о условима и процесима који стварају континуитет и промене током времена у биопсихолошким карактеристикама људских бића, било током целог живота појединца, у смењивању генерација, ретроспективно кроз време које је прошло или проспективно, на начин импликација које ће оне имати на ток људског развоја у будућности (Bronfenbrenner, Evans 2000: 117). Феномен развоја односи се на животни циклус појединца, али и на развој у смењивању генерација, те на историјско време, и прошло и будуће (Bronfenbrenner, Evans 2000: 793). Аутори, наиме, сматрају да сукцесивне генерацијске промене и развој нису мање важни концепти од развоја појединца током његовог животног века Bronfenbrenner, Evans 2000: 796). Бронфенбренер током развоја своје теорије остаје веран феноменолошкој перспективи, па тако и у зрелој верзији екологије људског развоја наглашава важност искуственог, односно доживљеног: „Научно релеватне одлике средине за људски развој не укључују само њене објективне карактеристике већ и начин на који се оне субјективно доживљавају од стране особе која у тој средини живи" (Bronfenbrenner, Evans 2000: 797). Наиме, људски развој се не може објаснити искључиво узимајући у обзир утицај објективних карактеристика на развој појединца. Доживљеност пак истих, од стране особе у развоју, носи емоционалну и мотивациону потентност, и управо ове субјективне „силе” нарочито доприносе развоју (Bronfenbrenner, Evans 2000: 797).

\section{Кључне одреднище биоеколошког развојног модела}

Проксимални прочеси. Биоеколошки модел у својој потпуној форми може се сажети у неколико кључних поставки. Људски развој се, наиме, одвија кроз процесе прогресивно усложњавајућих интеракција између активног, биопсихолошког људског бића и особа, објеката и симбола у његовом непосредном окружењу. Како би те интеракције имале неког учинка на развој, оне се морају одвијати редовно, током одређеног периода. Управо ове трајуће форме интеракције у непосредном окружењу у које особа ступа означавају се као проксимални процеси (Bronfenbrenner, 1995: 620, Bronfenbrenner, Evans, 2000: 117, Bronfenbrenner, Morris, 2006: 797). Као примери проксималних процеса могу бити наведене активности неговања бебе, играња са дететом, активности заједничке игре деце, групна или индивидуална игра, читање, учење нових вештина, атлетских активности, решавање проблема, планирање, извођење задатака и стицање знања (Bronfenbrenner, 1995: 620). За децу учешће у оваквим активностима развија способности, мотивацију, знања и вештине да ступају у ову врсту интреакције касније у животу (Bronfenbrenner, Morris, 2006: 797). Проксимални процес подразумева трансфер енер- 
гије између особе у развоју и особа, објеката и симбола у његовом непосредном окружењу; тај трансфер може ићи од особе до поменутих чинилаца, од чинилаца до особе, и исто тако може узети оба смера. Проксимални процес је заправо „покретач развоја” (Bronfenbrenner, Evans 2000: 118), и то примарни (Bronfenbrenner, Morris, 2006: 798); самим учешћем у тој врсти активности, индивидуа почиње да осмишљава свет око себе и да разуме своје место у њему, истовремено мењајући постојећи поредак, док се у исти уклапа (Tudge et al., 2009: 200). Као такав, он може имати два могућа учинка на развој појединца, односно два могућа исхода, и то развој компетенције - стицање и даљи развој знања и вештина, било интелектуалних, физичких, социо-емоционалних, или њихових комбинација или стварање дисфункције у развоју - показивање потешкоћа у постизању и одржавању контроле и интеграције у понашању у одређеним ситуацијама (Bronfenbrenner, Morris 2006: 803). Поставља се питање који проксимални процес ће имати један, а који други поменути исход. Аутори уводе термин изложеност као дистинктивни појам од кога зависи појава једног или другог могућег учинка на развој (Bronfenbrenner, Evans 2000: 118). Изложеност се заправо односи на обухватност контакта који се догађа између особе у развоју и проксималних процеса у које је она укључена. Изложеност се разликује по трајању, учесталости, предвидивости, времену када се догађа и интензитету одвијања. Из свега наведеног, аутори закључују о капацитету проксималних процеса да делују: облик, снага, садржај и правац на који проксимални процеси утичу на развој варирају као функција карактеристика особе у развоју, контекста окружења - и непосредног и посредног, и социјалних константи или промена које се дешавају током живота, и историјског периода током ког је особа живела, и свакако од природе развојних исхода под датим условима. Односно, развојни исход у некој каснијој временској тачки јесте заједничка функција процеса, карактеристика особе у развоју, природе непосредног „лице у лице” контекста окружења у коме појединац живи и дужине и фреквенције временског интервала током кога је особа у развоју била изложена одређеном процесу у одређеном окружењу (Bronfenbrenner, Evans, 2000: 119, Bronfenbrenner, Morris, 2006: 798). Како би употпунио појашњење своје теорије, Бронфенбренер потенцира и још неке битне одлике овог развојног концепта, и то: да би се развој догодио, појединац мора бити укључен у одређену активност, мора бити активан; да би проксимални процеси имали ефекта, морају се редовно одвијати, током одређеног временског периода, и то довољно дуго да би се повећавао степен њихове сложености; развојно ефикасни проксимални процеси увек су реципрочног карактера, односно утицај мора постојати у оба смера; проксимални процеси се не односе само на интеракцију појединца са другим љу- 
дима већ и са објектима и симболима, али тако да ови изискују пажњу, истраживање, манипулацију, елаборацију или имагинацију, односно неку врсту активности над истим (Bronfenbrenner, Morris, 2006: 798).

Поменуте две основне претпоставке биоеколошког развојног модела функционишу међузависно и могу подлећи емпиријским проверама. У том смислу, Бронфенбренер је понудио операциони истраживачки дизајн који дозвољава њихово симултано истраживање - „Процес-Особа-Окружење-Вријеме”” модел (Bronfenbrenner, Morris, 2006: 798). Основна сврха овог модела је у могућности његове истраживачке примене како би се проверио низ хипотеза од којих се заправо састоји Бронфенбренерова теорија људског развоја. Сам аутор је на више места експлицирао овај захтев и апликациону сврху не само понуђеног модела већ целе теорије „у развоју” да би се постулати на којима биоеколошка теорија почива могли истраживачки тестирати (Bronfenbrenner, 1977: 529, Bronfenbrenner, 1995: 62, Bronfenbrenner, Evans, 2000: 117).

Поменуте четири компоненте су синергијски међузависне, односно утицај Особе и Контекста на Процесе (самим тим на развој) није просто адитивног карактера; наиме, ова два чиниоца се мултиплицирају, међусобно оснажују и чине да њихов утицај на развој представља више од простог збира појединачних елемената, што Бронфенбренер поткрепљује истраживачким налазима (Bronfenbrenner, Morris, 2006: 800, 801). Појаснићемо значење преостала три поменута елемента биоеколошког развојног модела.

Особа. Карактеристике особе заправо се појављују на два начина у биоеколошком моделу развоја: најпре као један од елемената који утичу на форму, снагу, садржај и правац деловања проксималних процеса, али и као развојни исход истог тог деловања - дакле, и као индиректни фактор и као продукт процеса развоја (Bronfenbrenner, Morris, 2006: 798). Иако је Бронфенбренер признавао важност биолошких и генетских аспеката личности, много више пажње посветио је личним карактеристикама које појединац уноси у било коју социјалну интеракцију у којој je (Tudge et al., 2009: 200, 201). Бронфенбренер разликује три врсте „процеснорелевантних” карактеристика особе, које је одредио као карактеристике силе, захтева и ресурса особе. Карактеристике захтева су оне које делују као непосредни стимулус на своје социјално окружење, односно на друге особе и заправо могу утицати на почетну интеракцију између особа због очекивања која се по аутоматизму дешавају (Bronfenbrenner,

\footnotetext{
3 „РРСТ” (енгл.) - акроним од назива кључних компоненти биоеколошког модела:
} Process - Процес, Person - Особа, Context - Окружење, Time - Време. 
Morris, 2006: 812). У ове карактаристике спадају године, пол, боја коже и физички изглед (насмејано или тужно дете, хиперактивност или пасивност, атрактивна или неатрактивна појавност и слично). Карактеристике ресурса особе су оне које се односе на њихове биопсихолошке капацитете, који утичу на капацитет организма да се ефективно укључи у проксималне процесе (Bronfenbrenner, Morris, 2006: 812). Оне нису непосредно појавне (мада некад могу бити и то) и односе се на менталне и емоционалне капацитете као што су претходно искуство, вештине и интелигенција, али и на материјалне и социјалне, као што су домаћинство, квалитет исхране, брижни родитељи, образовне могућности и слично. Напослетку, ту су и карактеристике силе, које се односе на активне бихевиоралне диспозиције које могу утицати као покретачи проксималних процеса или се на другој страни ометати, заустављати појаву истих, односно које могу бити развојно генеративне или развојно ометајуће. Уопштено, оне се манифестују у темпераменту, мотивацији, истрајности и сличном; у ометајуће спадају импулсивност, експлозивност, агресивност, насилност, стидљивост, апатичност и слично, док су генеративне особине знатижељност, иницијативност, респонзивност, спремност да се реагује и слично (Bronfenbrenner, Morris, 2006: 810, 811). Бронфенбренер је сматрао да двоје деце могу имати сличне ресурсне карактеристике, али да њихов развојни пут и развојни прелази могу бити посве другачији, у зависности од њихових карактеристика силе.

Окружење. Када је реч о компоненти контекста, односно окружења, оно се, као и у почетној варијанти теорије из седамдесетих дефинише као „скуп угнеждених структура, од којих је свака садржана у следећој" (Bronfenbrener, 1977: 514 ). Но, о контексту се више не говори само у терминима концентрично угнеждених система већ се акценат ставља на оно што је „гравитациони центар” истих, односно тежиште биоеколошке парадигме, а то су заправо проксимални процеси. У том смислу, дефиниција микросистема из 1979. године се надопуњује и добија следећи облик: „Микросистем је образац активности, социјалних улога и интерперсоналних односа доживљених од стране особе у развоју у непосредном лице-у-лице окружењу са специфичним физичким, социјалним и симболичким одликама које позиваjу, омогућавају или ометају укључивање у непрекидну, прогресивно усложњавајућу интеракцију са, и активност у, непосредном окружењу" (Bronfenbrener, 1994: 39). Управо у непосредном окружењу микросистема одвијају се проксимални процеси који стварају и одржавају развој, а њихова моћ да то чине зависи у великој мери од садржаја и структуре самог окружења (Bronfenbrenner, 1994: 39, Bronfenbrenner, 1995: 638). Када је о односима реч, Бронфенбренер претпоставља следеће: да би се уопште људско биће интелектуално, емоционално, социјално и морално развило, оно нужно мора учествовати у 
прогресивно усложњавајућим реципрочним активностима, редовно, током одређеног временског периода, са једном или више особа са којом развија јаку, међусобну и ирационалну ${ }^{4}$ везу, а која је посвећена његовом развоју по могућности до краја живота (Bronfenbrenner, Evans, 2000: 122; Bronfenbrenner, Morris, 2006: 816).

Bријеме. Изнимно важну улогу у свим развојним теоријама, па и у овој, игра концепт времена. Бронфенбренер најпре уводи појам хроносистема, средином 80-их година прошлог века; за разлику од традиционалног поистовећивања појма времена у истраживањима људског развоја са хронолошком доби појединца, односно са променама које се појединцу догађају како постаје старији, у еколошком моделу развоја разматрају се промене које се догађају током времена не само унутар индивидуе већ и у окружењу, са свакако динамичким односом између ова два процеса - на пример, промене у породичној структури током животног циклуса, социо-економском статусу, запослењу, пребивалишту и слично (Bronfenbrenner, 1986: 724). Притом, аутор разликује нормативну (полазак у школу, пубертет, запослење, венчање, пензионисање) и ненормативну (болест или смрт, развод, пресељење) врсту искустава, које се догађају током животног века појединца и утичу на његов развој (Bronfenbrenner, 1988: 41).

Фактор времена више се пута појављује и у потпуној теорији у Бронфенбренеровим радовима од 90-их година, но, како аутор истиче, може се десити да његово прво појављивање прође унеколико незапажено; реч је, наиме, о основној пропозицији биоеколошког модела, којом се истиче неопходност честих и током одређеног времена трајућих проксималних процеса како би исти били ефективни по развој појединца (Bronfenbrenner, Morris, 1998: 996, prema Bronfenbrenner, Evans 2000: 117). Следствено томе, Бронфенбренер закључује да је „степен стабилности, конзистентности и предвидивости током времена у било ком елементу система који чини екологију људског развоја критичан за ефективан рад тог система" (Bronfenbrenner, Morris, 2006: 820). Овај став као своју истраживачку последицу има инсистирање на томе да се процени степен стабилности насупрот нестабилности карактеристика Процеса, Особе и Окружења на свим нивоима еколошког система, кроз време. Бронфенбренер и Морисова су фактор времена поделили на три потфактора, и то: микровреме, односно време које обухвата догађаје током неке одређене активности; мезо-време, које обухвата онај временски распон у коме се неке активности и интеракције одвијају конзистентно у окружењу особе у

\footnotetext{
${ }^{4}$ Термин ирационални аутор објашњава на следећи начин: „Укратко, неко мора бити луд за дететом” (Bronfenbrenner, 1981: 38), односно, ирационалну везу са неким имамо ако је та особа „прва коју бисмо покушали да спасимо у пожару” (Bronfenbrenner, Morris, 2006: 816).
} 
развоју; макровреме, односно хроносистем, који се односи на узрасну доб у којој индивидуа у развоју искуси последице неких историјских догађаја (Tudge et al., 2009: 201). Време по себи, али и временски тренутак (у односу на појединца у развоју) у ком се нешто одвија изузетно су важни елементи еколошке теорије, јер се сви поменути аспекти (сама особа у развоју, типови активности и интеракције у које ступа, или сами микросистеми у којима се односи одвијају) могу схватити као релативно константни или пак променљиви (Tudge et al., 2009: 201). Концепт времена у биоеколошкој теорији Бронфенбренер је засновао на неколико кључних принципа: индивидуални развојни пут појединца је уграђен у условима и догађајима који се дешавају током историјског периода у коме особа живи и снажно обликован њима; значајан фактор који утиче на развој је временски тренутак биолошких и социјалних промена у нечијем животу, у односу на њихову доб, очекивања од улоге у којој су, те уопште могућности које неко има током живота; животи чланова једне породице су међузависни - начин на који један члан породице реагује на одређене догађаје током времена или промену улога која га је задесила значајно утиче на развојни ток осталих чланова породице, у оквиру једне генерације, али и кроз следеће генерације (Bronfenbrenner, 1995: 642, 642). Време се сада посматра као чинилац окружења, и то не само током нечијег животног циклуса већ и у смислу историјског времена (Bronfenbrenner, 1994: 40). Реч је заправо о променама у окружењу током времена, или, како аутор сам закључује, о „простору кроз време: окружењу у трећој димензији" (Bronfenbrenner, 1995: 641).

\section{УМЕСТО ЗАКЉУЧКА - \\ ИЗАЗОВИ БИОЕКОЛОШКЕ ТЕОРИЈЕ У БУДУЋНОСТИ}

Бронфенбренер у низу радова посебно тематизује питање породице, као основног микросистема и установе васпитања и образовања, али исто тако и као важног социолошког ентитета. Низ је закључака присутних у свим ауторовим анализама, заснованим углавном на прегледу и сажимању обимне истраживачке грађе о стању у америчким породицама. У том смислу, Бронфенбренер истиче присутност феномена алијенације, која своје порекло има пре свега у променама у институцији породице, односно дисорганизацији истих, која није по себи њихова карактеристика, већ је условљена околностима у којима породице живе (Bronfenbrenner, 1974: 56). Све наиме упућује на ерозију породичне структуре или „еколошку ерозију” као последицу пораста запослености мајки, великог броја развода и једнородитељских породица (Bronfenbrenner, 1974: 53, 54, Bronfenbrenner, 1981: 38, Bronfenbrenner, 1984: 53), опадање вишегенерациј- 
ских породица, те пораст броја особа које уопште не заснивају породицу (Bronfenbrenner, 1981: 39, Bronfenbrenner, 1984: 54). Аутор наглашава да добробит деце у једној нацији највише зависи од статуса који у истој имају жене, односно мајке (Bronfenbrenner, 1974: 57).

С обзиром на стање које евидентира, Бронфенбренер проблематизује питање социјалних политика које оцењује као неадекватне у борби против урушавања капацитета институције породице. Осамдесетих Бронфенбренер износи став како је за здрав развој појединца, узимајући у обзир све промене у функционисању породице, неопходно да дете ступа у трајуће, ирационалне односе са једним или више одраслих у заједничким активностима (проксимални процеси), додајући притом како та укљученост одраслих захтева заправо јавну политику и праксу која даје могућности, статус, изворе, охрабривања, пример и пре свега време за родитељство, примарно од стране родитеља, али и од стране других одраслих, у дому или ван дома (Bronfenbrenner, 1981: 39). Јавна политика усмерена на породице и њихову добробит заснована је пак на незваничном дефицитарном моделу (Bronfenbrenner, 1981: 40, Bronfenbrenner, 1984: 65), који је такав да ако заправо желите да будете корисници услуга које ће вас као породицу или њене чланове штитити, односно да будете „комплетна људска бића”, морате да докажете да „сте довољно тога погрешно урадили" (Bronfenbrenner, 1981: 40, Bronfenbrenner, 1984: 66). Насупрот томе, Бронфенбренер предлаже такве јавне политике које ће значити „формални систем изазова и подршке који ће производити и оснаживати информални систем изазова и подршке, а који ће, заузврат смањити потребу за формалним системом подршке"; реч је наиме о посреденом подржавању и оснаживању капацитета породице као установе „која је једина способна за: стварање и одржавање људских бића људским" (Bronfenbrenner, 1984: 67, Bronfenbrenner, 1986: 738).

Бронфенбренер и Морис крајем 20. века истичу феномен „растућег хаоса" у породицама, школама, вршњачким групама и другим окружењима у којима одрастају деца (Bronfenbrenner, 1995: 644, Bronfenbrenner, Evans, 2000: 120; Bronfenbrenner, Morris, 2006: 823), и упоредо са тим, урушавање у домену њихових карактера и компетенција. Тај хаос „подрива стварање и стабилност односа и активности које су кључне за психолошки развој” (Bronfenbrenner, 1995: 644), односно подрива проксималне процесе као покретаче развоја. Развојни исходи на које упућују аутори израз су пре свега развојног нереда не у когнитивном, нити у емоционалном, већ у социјалном домену. Исто тако овај развојни хаос карактеристичан је за „обе стране једначине": на левој страни постојећи је неред у развојним покретачима (не постоји координација између социјалних система на микронивоу, а такође ни у међусистемским односима између ових непосредних окружења), што на десној страни једначине узрокује 
хаос у развојним исходима (јер се обрасци свакодневног понашања преносе и рефлектују на дугорочну посвећеност и упућеност појединца на добробит других људи, оних из његовог непосредног окружења, и шире, до коначне посвећености добробити друштва у целини) (Bronfenbrenner, Evans, 2000: 120). Аутори закључују, на основу података анализираних током неколико последњих деценија двадесетог века за Сједињене Америчке Државе да постоји прогресивно опадање бриге за добробит других људи - исказано пре свега не речима, већ делима (Bronfenbrenner, Evans, 2000: 121). У том смислу, Бронфенбренер и Еванс као кључни развојни изазов и проблем 21. века проглашавају управо поменуто расуло и хаос у социјалном развоју појединца. Управо је ово био импулс за следећи неопходан „научни корак” ових аутора: развијање и теоријског модела и одговарајућег дизајна истраживања за даље научно истраживање ефеката растућег хаоса и начина његовог деловања, као и идентификовање могућности за његово смањење и потенцијално преокретање истог (Bronfenbrenner, Evans, 2000: 121). Улога хаоса у биоеколошком моделу може се описати у терминима „хаотичног система”, који карактерише „френетична активност, недостатак структуре, непредвидивост у свакодневним активностима и висок ниво амбијенталне стимулације" (Bronfenbrenner, Evans, 2000: 121). Сумирајући налазе бројних истраживања, закључује се како овакви системи могу: 1. ометати проксималне процесе који доприносе развоју компетенција и 2. стварати проксималне процесе који воде деструкцији; наиме, хаос има потенцијал да опструира развој и одржавање оних процеса који погодују развоју компетенција, а да директно води оним проксималним процесима који ометају социјални развој. Растући хаос који истичу ови аутори у огроман ризик доводе развој социјалних компетенција, односно њиховог корена - а то су оне везе које, током времена, укључују и обавезују на акцију у прилог добробити другог, изван нашег сопственог интереса. Управо на основу овог закључка аутори употпуњују своју ранију визију онога што је потребно за људски развој, истичући како „да би се развило - интелектуално, социјално, емоционално и морално - људско биће, било дете или одрастао човек, то захтева - за све њих - исту ствар: активно учешће у прогресивно усложњавајућим реципрочним интеракцијама са особом са којом он или она развијају јаку, заједничку, ирационалну везу и која током времена постаје одана за добробит и развој једних и других, по могућности за цео живот" (Bronfenbrenner, Evans, 2000: 122). Бронфенбренер и Еванс стоје на позицијама историјског тренутка који се одликује растућим хаосом не само у породицама већ у свакодневном окружењу појединаца ма које доби; у том смислу, кључни изазов савремене развоје науке у 21. веку је управо „наново стварање социјалног развоја" (Bronfenbrenner, Evans, 2000: 123). 


\section{ЛИТЕРАТУРА}

Bronfenbrenner, U. (1974): The origins of alienation, in Scientific American, Vol. 231 (2), Scientific American, Inc. pp. 53-61. DOI: 10.1038/scientificamerican0874-53, preuzeto: 28. 2. 2015

Bronfenbrenner, U. (1977): Toward an Experimental Ecology of Human Development, American Psichologist, pp. 513-531. Dostupno na: http://cac.dept.uncg.edu/ hdf/facultystaff/Tudge/Bronfenbrenner\%201977.pdf, preuzeto: 27. 2. 2015.

Bronfenbrenner, U. (1981): Children and families: 1984? In Society, Vol. 18, Issue 2, New York: Springer, pp. 38-41. DOI: 10.1007/BF02694667, preuzeto: 28. 2. 2015.

Bronfenbrenner, U. (1984): The changing family in changing world: America first? In Peabody Journal of Education, Vol. 61, Issue 3, London: Taylor and Francis, pp. 52-70. DOI: 10.1080/01619568409538445? journalCode=hpje20, preuzeto: 26. 2. 2015.

Bronfenbrenner, U. (1986): Ecology of the Family as a Context for Human Development: Research Perspectices, in Developmental Psychology, Vol. 22, No. 6, American Psychological Association, Inc., pp. 723-742. DOI: 10.1037/0012-1649.22.6.723, preuzeto: 27. 2. 2015.

Bronfenbrenner, U. (1988): Interacting systems in human development. Research paradigms: present and future in Bolger, N. et.al (ed.): Persons in Context: Developmental Processes, pp. 25-49, New York: Cambridge University Press.

Bronfenbrenner, U. (1994): Ecological models of human development, in International Encyclopedia of Education, Vol. 3, 2nd. Ed. Oxford: Elsevier. Dostupno na: http://www.google.rs/url?sa=t\&rct=j\&q=\&esrc=s\&source=web\&cd=3\&ved=0CD oQFjAC\&url=http\%3A\%2F\%2Fwww.columbia.edu\%2Fcu\%2Fpsychology\% 2Fcourses\%2F3615\%2FReadings\%2FBronfenbrennerModelofDevelopment $\% 252$ 8short\%2520version\%2529.pdf\&ei=QLD-VPo0w_vKA-jfgtAE\&usg= AFQjCNG9vg294UJR-CbEuhxqEQXHiAaRRg, preuzeto: 27. 2. 2015

Bronfenbrenner, U. (1995): Developemntal Ecology Through Space and Time: A Future Perspective, in Moen, P., Elder, G.H., Luscher, K. (eds.): Examining lives in context: Perspectives on the ecology of human development, pp. 619-647. Washington DC: American Psychological Association.

Bronfenbrener, J. (1997): Ekologija ljudskog razvoja [Ecology of Human Development], Beograd: Zavod za udžbenike i nastavna sredstva.

Bronfenbrenner, U., Ceci, S.J. (1994): Nature-Nurture Reconceptualized in Developmental Perspective: A bioecological Model in Psychological Review, vol. 101, No. 4, pp. 568-586. American Psychological association, Inc. Dostupno na: http://www.ncbi.nlm.nih.gov/pubmed/7984707, preuzeto 1.3.2015.

Bronfenbrenner, U., Evans, G.W. (2000): Developmental Science in the 21st Century: Emerging Question, Theoretical Models, Research Design and Empirical Findings in Social Development, 9, 1, pp. 115-125, Blackwell Publishers Ltd. DOI: 10.1111/1467-9507.00114, preuzeto: 1.3. 2015.

Bronfenbrenner, U. Morris, P. (2006): The Bioecological Model of Human Development, in Lerner, M.R. (ed.) (2006): Handbook of Child Psychology, Volume 1: Theoretical Models of Human Development, pp. 793-828. New Jersey: John Willey and Sons, Inc.

Darling, N. (2007): Ecological Systems Theory: The Person in the Center of the Circles, in Research in Human Development, 4:3-4, 203-217, London: Routledge. DOI: 10.1080/15427600701663023, preuzeto: 20. 2. 2015.

McMillan, B. (1990): An ecological perspective on individual human development, in Early Child Development and Care, 55: 1, pp. 33-42, London: Routledge. DOI: 10.1080/0300443900550106, preuzeto: 20. 2. 2015. 
Rosa, M.E., Tudge, J. (2013): Urie Bronfenbrenner's Theory of Human Development:Its Evolution From Ecology to Bioecology, in Jorunal of Family Theories and Review 3, pp. 243-258. DOI: 10.1111/jftr.12022/abstract, preuzeto: 3. 3. 2015.

Tudge, R. H. J., Mokrova, I., Hatfield, E. B., Karnik, B. R. (2009): Uses nad misuses of Bronfenbrenner's Bioecological Theory of Human Development in Journal od Family Theory and Review, 1, pp. 198-210. Dostupno na: https://www.uncg. edu/hdf/facultystaff/Tudge/Tudge,\%20Mokrova,\%20Hatfield,\%20\&\%20Karnik, \%202009.pdf, preuzeto: 22. 2. 2015.

\title{
FROM ECOLOGICAL TO BIOECOLOGICAL THEORY OF HUMAN DEVELOPMENT - MAN AND ENVIRONMENT IN DIALOG
}

\author{
Jovana Marojević \\ Faculty of Philosophy, University of Montenegro, Podgorica, Montenegro
}

\section{Summary}

The original, ecological theory of human development conceptualized human development in interaction with context, through four levels of environment - microsystem, mezo-system, egzo-system and macro-system. The focus of interest of the author during the development of the theory moves on personal factors, primarily, through realizing the key importance of proximal processes for the development of the individual and the characteristics of developing a human being, rather than sole or exclusive feature of the environment in which development takes place.

Bio-ecological theory of human development is constructed with, by the author made explicit purpose to serve as a research model, contributing to a better understanding of the development of the nowadays human beings. Conducting a bio-ecologically valid research would also mean "checking" the theory, which was Bronfenbrenner's unambiguous intention. However, according to some analyses, to date, very few studies can carry a quality bio-ecological research, because it usually retains the explanation of the features of the environment and the interaction of individuals with the same environment, ignoring a number of key drives of human development recognized by Bronfenbrenner.

The biological research as its indispensable guidelines has to have an analysis proximal processes (lasting interactions in which the developing person directly participates), the person himself/herself (especially their process-relevant characteristics), environment (micro, mezo, egzo and macro system) and time (micro, mezo and macro-time). The proximal processes as key generators of human development should be the focus of the bio-ecological researcher. Especially since, as Bronfenbrenner detected primarily through family dysfunction today, these "crippled" proximal processes are recognized as the main cause of "ecological erosion,", that is, the basic interest for the welfare of another human being. 